\title{
EchoGéo
}

$17 \mid 2011$

Activités extractives

\section{New geographies of resource extraction}

Introduction

\section{Géraud Magrin et Laetitia Perrier-Bruslé}

\section{(2) OpenEdition}

Journals

Édition électronique

URL : https://journals.openedition.org/echogeo/13093

DOI : $10.4000 /$ echogeo.13093

ISSN : 1963-1197

Éditeur

Pôle de recherche pour l'organisation et la diffusion de l'information géographique (CNRS UMR 8586)

Référence électronique

Géraud Magrin et Laetitia Perrier-Bruslé, « New geographies of resource extraction », EchoGéo [En ligne], 17 | 2011, mis en ligne le 09 mai 2012, consulté le 11 août 2021. URL : http://

journals.openedition.org/echogeo/13093; DOI : https://doi.org/10.4000/echogeo.13093

Ce document a été généré automatiquement le 11 août 2021.

EchoGéo est mis à disposition selon les termes de la licence Creative Commons Attribution - Pas d'Utilisation Commerciale - Pas de Modification 4.0 International (CC BY-NC-ND) 


\title{
New geographies of resource extraction
}

\author{
Introduction
}

Géraud Magrin et Laetitia Perrier-Bruslé

\section{NOTE DE L'ÉDITEUR}

This dossier has been coordinated by Géraud Magrin and Laetitia Perrier-Bruslé who would like to thank all the reviewers of the articles, as well as Nicolas Donner for his help with editing the introduction.

1 Following up on a previous dossier devoted to mining in West Africa, ${ }^{1}$ EchoGéo now extends its exploration of the geography of resource extraction today by focusing on some new areas (Burkina Faso, Guyana, Gabon, Gulf of Guinea, South Asia, and East Africa) and a variety of resources (gold, iron, oil, precious stones). The five articles in this dossier explore a range of sites, strategies, relationships between parties involved and between the parties and their environments. In all these processes, space functions as an explanatory dimension or significant context.

2 This introduction is intended to put these articles into perspective, identifying the invariant factors and new parameters that are now shaping the outlines of the geography of resource extraction; it then presents and in some cases comments on the specific contribution of each article.

\section{The extractive base and global contradictions}

Natural resource extraction is soaked in history, and in suffering. At a time when the virtual world seems to be in the ascendant - with the apparent decrease in importance of production of goods in national economies, the hypertrophic growth of the digital sphere, the era of Facebook and of knowledge industries - it bears remembering that more than ever, this all starts, or at least is all made possible, with the availability of 
the natural substances that lie beneath our feet. Liquid modernity (Bauman, 2006) has a vital need of energy and of solid physical objects. Today's globalization is born from the alchemy that transforms raw materials extracted from deep below ground into natural resources (Raffestin, 1980). At least since the industrial revolution of the nineteenth century, these resources underpin the functioning of the global system (Gottmann, 1952). They provide the energy (coal, oil, uranium) essential in an increasingly bulimic world, as well as the raw materials for manufacturing all sorts of things, including heavy (iron, copper, bauxite, etc.) and light (rare metals and rare earths), as well as materials with a symbolic value that varies in importance (gold, diamonds, precious stones).

But our age is an anxious one, verging on the ungrateful. The extractive operations that support the refinements of contemporary globalization have a bad name. They are linked with many kinds of degradation of the environment: consumption of carbonbased energy is a major cause of global warming; some substances though harmless in their inert form become harmful in the course of extraction, transport, or subsequent use, rendering their "excesses" ${ }^{2}$ dangerous because difficult to control (technically and geographically), as in the case of oil-based marine pollution or nuclear accidents; all resource extraction threatens, to varying degrees, the local environments in which it takes place, and this damage is less and less tolerated. The extraction of raw materials from underground is also a political liability: this has given rise to the concept of the "natural resource curse," which links poverty with wealth derived from natural resources in an uncompromising vicious circle. In countries with weak institutions, in particular, income from mining royalties tends to be attended by a group of misfortunes that can be both macro-economic (stagnation of the productive sectors, indebtedness) and political (authoritarianism, corruption, conflict) and tend to perpetuate underdevelopment (see the critical synthesis by Rosser, 2006; Le Billon, 2005, on conflict; Magrin, 2011). Lastly, the fact that producers and consumers only partly overlap means that the most strategic of these natural resources becomes a central issue in international relations and tensions (Gabriel-Oyhamburu, 2010).

The extremely sensitive nature of extraction and its problems thus reflects the contradictions on which the modern world is built. Geography and geopolitics combine pre-existing features with new dynamics. The articles in this dossier, beyond the specific situations they describe, can help to decode the importance and meaning of these developments.

Not everything is new in the geography of resource extraction. Geology is in large part static. The major producers of principal extractive resources are stable entities. The geopolitical conditions based on them are largely permanent: the giant oil fields in the Middle East, North Africa, Russia, and Venezuela, support royalty-based economies and more or less authoritarian, even violent, political systems (Martinez, 2010). These systems are central to international relations in which states are dynamically asymmetric, depending on whether they possess resources, the technology to extract them, both of these, or neither; the control of distribution capacity constitutes a key asset (Raffestin, 1980). The article by Romain Dittgen clearly sets out the characteristics of the confrontation between the Chinese giant and the little Gabon whose iron it is attracted by. Africa is still stuck in its historical role as a subordinate provider of natural resources, including extractive ones, for the global system, even if that role does not exclude a (variable) degree of autonomy (Bayart, 1989). 
7 Relationships to resources are also characterized by cyclic phenomena, even if, here as elsewhere, history operates in something more like a solenoid movement than an eternal recurrence. In one example of this, the fear that resources would be used up, expressed forcefully during the oil crises of the 1970s, led the Club of Rome to recommend zero growth long before the current fashion for limits on growth. Since the late 1990s sustained global economic growth, driven entirely by the major emerging countries since the 2008 financial crisis, has boosted commodity prices, particularly those of extractive resources. The end of the age of easily accessible resources has geographic implications: it triggers the race for new resources hitherto protected by inaccessible environments, whether ecological (the poles, very deep ocean sites, dense forests) or geopolitical. Modern extractive exploration, by crossing these new frontiers ${ }^{3}$ in areas that may be under the scrutiny of world public opinion due to their high ecological value, generates new environmental and political risks, and hence new techniques for managing risk and protecting mining operations, as is shown in Nicolas Donner's article on the immunization of oilfield enclaves.

8 Just as cyclical are the commodity markets, which sustain a dialectical relationship with state resource management policies. Each boom (of energy or minerals) triggers an upsurge in extractive nationalism, as ephemeral as the royalties that made it possible. The 1960s and 1970s saw the nationalization of resources in several major oilproducing countries, the creation of OPEC, the increased presence on the world stage of some countries with extractive resources (such as Gabon with its oil and Mobutu's Zaire with its copper). The 2000s saw a corresponding appearance of oil and mining nationalism in other countries, including the nationalization of gas in Bolivia (PerrierBruslé, 2008), and the increased presence of Chavez's Venezuela and of tiny Equatorial Guinea in Central Africa. However, relationships are more complex than they might appear. The Arab Spring has swept away some clichés. It reminds us that oil is no more central than any other resource to all these political and geopolitical upheavals. Is the fall of Gaddafi the exception that proves the rule according to which some oil states are "sustainable failed states" (Soares de Oliveira, 2007)?

Major changes can also be in the spirit of the times. The fear of a shortage of resources combines with the fear of even wider threats, the foremost of them global warming. The issue of the local and global viability of the relations between societies and their environments has given rise to the paradigm of sustainable development, which is now unavoidable. Its influence on the worldwide geography of resource extraction remains to be analyzed. In Latin America and more recently in Africa, new movements are originating in civil society, sometimes led by those living in or near extractive sites (indigenous peoples and other concerned inhabitants), complemented by national and international NGOs concerned with human rights or the environment; these groups draw on the precepts of sustainable development to assert their rights to oversee the operations of large mining companies or state policies with respect to the handing over of natural resources. Instead of the fait accompli of former days, discussions focus on limiting the negative local impacts of extraction and improving transparency in the management of royalty revenues (see Magrin, 2011). The combined pressures of local communities, Western public opinion, and shareholders, as well as the bad experiences of the past, are encouraging large companies to go the route of corporate social and environmental responsibility (CSR). Thus, in an ultimate paradox, it has even been claimed that the exploitation of nonrenewable resources can support sustainable 
development, as is demonstrated by the iconic oil project in Chad (see Donner, 2003; Magrin, 2003, 2011). Jessica Oder's article on changes in the gold mining industry in French Guyana describes some thwarted attempts to make this reformed extractive industry serve the goals of sustainable development in a specific region.

What is the potential effect of these changes? To what extent is current rhetoric accompanied by real changes in corporate practice? And leaving aside those questions, what is the current impact of these mines on the geography of their host environment? Technological changes mean that mining no longer has the same economic ripple effects as in the past: mechanization at the site reduces employment opportunities and migration (Deshaies, 2007); neoliberal oil production and mining regulations promoted by the World Bank, especially in Africa, ${ }^{5}$ limit the level of extraction and control by the states concerned (Campbell, 2009). Mines no longer have the structural impact on urbanization and social density that they had in the past, for example in Southern Africa's copper belt (Ferguson, 1999). Facilities constructed in potentially hostile environments adopt the model of the enclave rather than the integrated adjunct (Magrin, van Vliet, 2005; Donner, 2009). Extractive facilities are implanted in previously staked out extraterritorial zones that contribute to the fragmentation of national territories, while at the same time they underpin the operation of contemporary globalized space (Antheaume, Giraut, 2005; Ferguson, 2006). But the potential impact of these archipelagos, especially the extractive ones, surely also resides in their ability to make use of the local and national context in which they exist and to structure it in return (Arrault, 2005). Extraction sites are now in the global spotlight. But the current expectation on the part of global society that developing countries should protect and set aside areas of high ecological value is difficult for those countries to accept when these areas contain natural resources. Ecuador's proposal to abandon exploitation of hydrocarbons in the Amazonia, in the Yasuni reserve, in exchange for compensation from the rest of the world, is not without interest. It could also inspire other countries that find they have to arbitrate the coexistence of oil extraction and biodiversity "hotspots" - such as Mauritania, which is tempted by the possibility of oil exploration on the edge of the Banc d'Arguin (Magrin et al., 2011). Is it true that supposedly ethical sustainable development will be so manipulated that it will serve only to protect extractive enclaves, as envisaged here by Nicolas Donner? Or, instead, will the national development of extractive resources in a new and better regulated context, or at least one open to discussion, make room for different options for sociopolitical systems based on royalty revenue, thus escaping the rut of the "resource curse" (van Vliet, Magrin, 2009), along the lines suggested by Conrad's Nostromo (Magrin, 2011)?

11 Another major change concerns the protagonists of the extraction industries. Along with the emergence of national public opinion on these issues and of civil society organizations, small companies (independents in the case of oil, "juniors" in mining) and companies from the major emerging countries have arrived on the international extraction scene. These latter two categories, though otherwise very different, are both seen as largely impervious to CSR because they do not have a global image to preserve in the eyes of consumers or shareholders - as is shown in Matthieu Thune's article about the operation of a goldmine in Burkina Faso by an English "junior." The rise of these small companies was first encouraged by the financialization that characterizes globalization today (Megret, 2011). They mainly specialize in initial prospecting and the exploitation of small deposits, or of deposits that are almost exhausted, where cost and operating conditions deter the bigger companies (van Vliet, 1998; Magrin, van Vliet, 
2005). Companies from emerging countries initially engaged in this type of operation and also invested in geopolitically risky environments or in countries out of bounds to Western companies, for example the Chinese oil companies who dealt with the Sudan while it was under embargo. More recently, their increased technological and financial capacity has enabled them to meet the competition with respect to almost all types of deposit. ${ }^{6}$ Thus the rise of Chinese, Indian, and Brazilian nationals, developing strategies for acquiring the reserves of raw materials that are strategic for supplying their expanding industries, is one aspect of the major global transformation marked by the relative decline of the old powers (US and Europe) and the shift of the global center of eco-demographic gravity to Asia.

These new players generate new relationships and new power-relations, both with host countries and with Western companies. It would be simplistic to see this new situation as merely an increase in competition between businesses: the players also need to complement one another because of the diversity of deposits - in size, operating conditions (accessibility, geopolitical challenges, regulation), and the stage at which exploitation takes place (initial exploration, beginning or end of the extraction cycle). All the participants need to work within the same system. Moreover, there is a fundamental difference between companies from the North and emerging ones with respect to CSR: ethical extraction seems to give the former a comparative advantage in the face of the threat posed by the latter (Soares de Oliveira, 2008). Conversely, the fact that companies from the South are less suspected of economic imperialism gives them an advantage in contract negotiations with left-wing governments who are anxious to end their historical inequality with the major Western powers. Examples of this are the concessions granted by Bolivia to the Indian company Jindal Steel and Power Limited for the exploitation of iron in Mutun, or the facilities accorded by these post-colonial countries to Petrobras (Brazil) and Petróleos de Venezuela SA (PDVSA) in the hydrocarbon sector. Yet it would be reductive to claim that these newcomers help keep the "resource curse" alive because their standards are bound to be lower than those of the major Western companies, or that their arrival on the scene is bound to lead to some sort of social and environmental "dumping." The few studies available on the subject, such as that on the environmental regulation of the China National Petroleum Corporation (CNPC) in Chad, indicate that the truth is more complex, and that there are significant similarities in company practices no matter what their origins, though they advance at different speeds and in different ways (van Vliet, Magrin, eds., 2011). Romain Dittgen's article here on Chinese plans for exploiting iron resources at Bélinga in Gabon shows, similarly, that Chinese strategies allow for frequent adjustments and turn out to be less subject to political goals and more responsive to market indicators than might have been expected.

\section{Five stories of resource extraction today}

13 Needless to say, the five articles included in this issue do not exhaust the complexity of the subject as briefly presented. They do offer a variety of topics, levels, and standpoints. Four natural resources are discussed: petroleum, iron, gold, and precious stones, in descending order of importance for the operation of the global economic system. The first two are basic to that operation, especially oil. The other two are significant for other reasons. Gold, although of little industrial use and relatively 
abundant, has maintained its value as a safe haven, despite (or in conflict with) all the changes caused by globalization. The current high price of gold has led to an upsurge in mining on every continent. The global geography of precious stones is less well known, apart from diamonds; the factors that affect them make is what distinguishes these precious stones from other extractive resources. The articles presented here also address different levels of activity: Matthieu Thune examines how a mine fits into its local environment; Jessica Oder and Romain Dittgen look at the issues relative to a specific industry (gold in Guyana) and a giant project (iron from Bélinga in Gabon) where the regions concerned are similar in size. Nicolas Donner and Rémy Canavesio take a global view, examining the processes specific to a type of resource (oil and precious stones respectively), the former focusing on examples from the Gulf of Guinea, the latter on South Asia and East Africa. The contributors investigate a range of specific topics: the impact of a mining project on the local community (gold in Burkina Faso, iron in Gabon); the thinking behind the security measures in oil enclaves; the factors that lead to reorganization of an industry, in a specific region (gold in Guyana) or globally (the geography of precious stones).

Matthieu Thune's article, “L'industrialisation de l'exploitation de l'or à Kalsaka, Burkina Faso : une chance pour une population rurale pauvre ?" ("The industrialization of gold mining in Kalsaka, Burkina Faso: an opportunity for a poor rural population?") is set in the context of the upsurge in industrial gold mining in West Africa during the 2000s (Campbell, 2009; Mbodj, 2011), a time when Burkina Faso was one of the last El Dorados. The mine, located in a poor region in the south of the Mossi Plateau that has long been extremely overpopulated, could be seen as providing an opportunity for the local people or alternatively as an additional source of problems. The mine was excavated on a hill where farming and panning for gold had coexisted well enough in the past, the latter providing valuable diversification in the rural economy. The article shows how, in Kalsaka as often elsewhere in West Africa, the compensation paid by the company carrying out the new resource extraction has taken fundamentally different forms for farmers and for traditional artisanal miners. Farmers' use rights are recognized and compensated; the individual beneficiaries' subsequent histories vary, but can often be predicted based on their previous situations. The losses suffered by traditional gold miners are not taken into account, despite the longstanding existence of this activity and the customary laws that regulate it. What explains this differential treatment? Perhaps it has less to do with the difference between above-ground and underground resources (the land itself in both cases is owned by the State, which grants land use rights to the local people) and more with the relationship of these practices to space, agriculture being more sedentary and gold panning more mobile. On the hill at Kalsaka, the mining industry has thus ousted artisanal extraction from the lode. But this activity was coming to an end in any case, because with the available techniques it was impossible to seek for gold at any great depth underground. Furthermore, the new mine's economic benefit for the local community is minimal: as always, the number of jobs is limited, and they are almost out of reach of the local people. The company maintains community relations in the form of lip-service and some paternalism, but real initiatives are minimal. The miners' low wages do not make up the shortfall resulting from the end of traditional extraction in the locality. All in all, the Kalsaka gold mine seems to have been neither an opportunity nor a complete disaster for the locals. The article ends by noting the need for comparison with other sites: is the poor return to the local community due to the strategy of a "junior" 
operator (an English company, Cluff Gold) with an unusually low interest in CSR practices? Or is it inherent in the enclave mentality inevitable in the mining industry today?

Jessica Oder's contribution, "Vers la structuration d'une filière aurifère 'durable' ? Le cas de la Guyane française" ("Towards the organization of a 'sustainable' gold-mining industry? The case of French Guyana"), discusses resources that are geologically continuous with the extractive base of West Africa, on the ancient continent of Gondwana. The apparent symmetry between Guyana and West Africa, and the comparisons it inspires, contribute significantly to the interest of this article, although the processes studied exist in radically different political contexts: an African state with weak regulatory capacity versus an overseas possession of France. In Africa the policy of courting investment in mining is justified primarily by the resources it will bring to the state (whereas employment is a demand put forward only by those who live in the mining areas - and a permanent source of dissatisfaction); in Guyana the encouragement of modern industrial exploitation of gold mines is a state policy, backed by the local authorities, intended to address the need for economic diversification and job creation at a time of population growth that is seen as intense by the standards of metropolitan France. Those principally involved in the gold industry in French Guyana today are small or very small businesses who struggle to meet the requirements imposed by the government, which seems to have been suddenly converted to the religion of sustainable development by the Grenelle de l'environnement of 2007. Therein lies the paradox of Guyanese gold mining, as analyzed by Oder: here, unlike Africa, the unprecedented rise in gold prices is accompanied by a production crisis in the official gold mining sector, due especially to illegal gold extraction. Is this because the state is too strong, stifling private initiative by imposing regulatory measures beyond the capacity of fragile small businesses? Or is it rather because it is too weak to support the mining companies, or to control vast areas of forest that are sparsely populated and liable to be infiltrated by the well-organized Brazilian garimpeiros (prospectors)? The article also suggests another interesting perspective. The development of gold mining as an industry in Guyana is enlisted in the service of political demands for autonomy: the regional council encourages mining as part of a policy of empowerment and recovery of resources long monopolized by the colonizer, in a way reminiscent of current dynamics in the Northern Province of New Caledonia, where there is a nickel boom. Development through mining can be interpreted either as a vector of political emancipation, or as an expression of commitment to a European concept of development (modern industries and the capitalistic and individualistic values that go along with them) opposed to alternative values that might have strengthened indigenous political dissent.

Romain Dittgen in turn addresses the capacity for change associated with the Chinese project for an iron mine at Bélinga in Gabon; a contract was signed in 2006, but work has not yet been started on it. The project is put into perspective through reference to the history of mining cycles in Gabon (Pourtier, 1989), to the situation in Africa during the 2000s, marked by massive Chinese investment in extractive resources (Alden, Large, Soares de Oliveira, 2008), and to relations between Gabon and China. The Bélinga project sees the meeting of Gabon's need for economic and diplomatic diversification with China's appetite for raw materials to feed its global factory. The asymmetry between the parties involved when the project was initially being discussed is not unlike that of Western multinationals in negotiations with African nations seeking to 
increase their royalty revenues. From the outset, the project was deeply political, in the sense that it was made possible by discussions at the highest level between the governments of China and Gabon. A Chinese company was chosen over a Brazilian competitor, under less than transparent conditions. The project forms part of China's overall strategy in Africa, claimed to be "win-win," in the form of assistance in kind (infrastructure) in exchange for control over raw materials. The exploitation of Bélinga's iron requires an initial investment of $\$ 2.2$ billion and four years of construction work. The construction projects include a railroad that will open up access to mineral deposits in a quasi-wilderness region, dams to provide energy, and an ore port capable of handling 20 million tonnes per year, among other things. Dittgen analyzes the potential after-effects both nationwide and in the region of production, as well as the uncertainty surrounding the project's implementation: the 2008 crisis and the fall in the price of iron play a role, as does political uncertainty in Gabon following the death of Omar Bongo, who had personally intervened in the rapprochement with the Chinese. His death was an opportunity for NGOs and the national media to criticize the terms of the contract, seen as unfavorable to the state as a whole, to local communities, and to the environment. Delaying the project led especially to questions about the "special case" of the Chinese, for whom short-term profitability is apparently secondary to long-term strategic aims - which would explain why political relations trumped financial calculations during negotiations over the project. The Bélinga project is also reminiscent of the iron mine at Falémé in Senegal, where the Indian steel giant Mittal obtained an exploitation license in exchange for promises of substantial investment in infrastructure and local employment, before pulling out as a result of the 2008 crisis. In Bolivia, the choice of the Indian company Jindal Steel to exploit the Mutun iron mine ( 40 billion tonnes) has led today to a parallel public debate about the company's ability to conduct exploitation on that scale and about the favors it has apparently received from the government. Whatever the truth of the matter, the lesser profitability of mining compared to petroleum extraction explains the hard-tointerpret global strategies of these giant companies, now often Chinese, Indian, or Brazilian. These companies balance very long-term thinking against the effects of short business cycles, sometimes only seeking to have control over reserve deposits, sometimes going a step further to their actual exploitation. These strategies make it all the more clear that the host countries are in a position of weakness in negotiating the conditions of exploitation.

17 Nicolas Donner's contribution borrows a medical metaphor to describe the ways in which oil extraction sites fit into their host environment. Starting with the paradox that movement worldwide depends on a powerful yet inert material, "Notes sur la dimension immunitaire des enclaves pétrolières" ("Notes on the immune system of petroleum enclaves") describes the techniques used to immunize the petroleum extraction system from the potential dangers of its host environment, as a necessary condition of the distribution of the resource. To do this he brings in various examples of such enclaves around the world, focusing on those in the most hostile regions, meaning wilderness and lawless areas, especially in Africa. Two chief types of immunization are discussed. Some oil-producing enclaves are designed to be as autonomous as possible from their surroundings. The core of those located in wilderness areas is an archetype of this approach, halfway between a hyper-modern city (which delivers an almost entirely artificial environment) and a space capsule (which delivers a very compact living space). Oil enclaves thus more or less perfectly 
approximate the model of the "absolute island," as Sloterdijk (2005) calls it. They also illustrate a paradoxical form of being in the world, characterized both by isolation visà-vis the immediate vicinity and connection to the rest of the world, especially to the other key points of the archipelago. There is a wide spectrum of immunization methods, right down to "petronaut" clothing, such as the long-sleeved garments worn by Exxon project staff in Chad to protect them from malaria. In inhabited areas, especially in the case of geopolitically sensitive regions of "fragile" states (in the terminology of the Bretton Woods institutions), immunization has a dual function, defensive and interventionist. The defensive function is ensured by a series of protective "coatings" (guards, walls, limited access areas) surrounding the facilities. The solidity of these barriers varies depending on the situation, but they are never fully sealed, thus allowing the extractive facilities to breathe and maintain a degree of flexibility in their external relations. The interventionist function concerns the control of working relationships with the host environment: this is where the lexical, ideological, and methodological arsenal of CSR and sustainable development language can be deployed successfully.

More broadly, Donner's article examines the uses of the ideology of sustainable development with respect to resource extraction systems. This dominant paradigm is not only a more or less successful response to the anger aroused by the most negative impacts of resource extraction in the 1990s; more fundamentally, it seems to function as one of the immunization strategies (used by both companies and large donors) introduced into extraction industries in response to the requirements of the dominant countries. Thus the paradigm of sustainable development, coupled with strategies for stabilization and local legitimation, fits as neatly with strategies for the security of energy supplies as it does with the sensitivities of public opinion in the West. Ethical values are manipulated to serve the "social license to operate" and to secure the zones of production - although in practice this does not mean that this strategy is always implemented smoothly. The Chad-Cameroon project financed by the World Bank is a good example of this approach and of its limitations. The article adopts the perspective of the petroleum industry and focuses on the point at which it is "grafted" onto the sites where extraction occurs. Reversing the perspective, looking at the intrusion of the petroleum industry from the point of view of the host environment, and the ways in which it supports, on various levels, imaginary constructions and industry strategies, could extend the argument of the article in an interesting direction. Lastly, it could be asked whether this interpretation of the oil enclaves' immunization techniques might be applicable to other forms of extraction: though on a much smaller scale, gold and diamond mining may be similar. However, very large mining projects, the kind that involve massive local infrastructure and create many jobs, would surely represent a rather different geographical model.

Lastly, Rémy Canavesio's article, "Croissance économique des pays émergents et géographie mondiale des pierres précieuses" ("Economic growth in emerging countries and the geography of precious stones") discusses less well studied resources that have distinct characteristics of their own. By the standards of the global oil and gas industries, they are economically trivial: the figures involved are in no way comparable, and they can be dismissed as having frivolous or merely symbolic value. But the geography of precious stones is complex, and shapes global industries with important results for local geographies. Extraction sites, channels, and markets vary depending on the precious stones concerned. Canavesio addresses the dynamics of the 
precious stone industry as a whole, but rather than focus on diamonds, the best known, he discusses the less well-known sapphires and rubies. The first goal is to understand the factors that affect their geographic distribution. Unlike oil, these factors are not geopolitical or strategic, and unlike gold, the precious stone industry is almost entirely unaffected by the liberalization of mining regulations, because it is mostly carried on in informal and artisanal ways. On the other hand, sites of consumption are partly due to longstanding historical and cultural factors, and changes in consumption patterns have a lot to do with macroeconomic dynamics. Global demand for precious stones is similar to that for automobiles: it is driven by the increasing wealth of emerging countries, whereas Western markets have been "mature" for a long time. Diamonds, whose production and consumption are generally detached from their country of origin, benefit from each rapid increase in wealth in a large population (see Brunet, 2004). However, the growing wealth of the major emerging countries does not express itself in the same ways. While the Chinese love jade, their thirst for (Western-style!) consumption is likely soon to make them turn to diamonds, as the Japanese have done. In India, by contrast, longstanding cultural resistance to Westernization is expressed in a continuing preference for rubies and sapphires. Increasing wealth has also transformed the geography of supply. Since the mining of precious stones is mostly artisanal, their high value makes this a profitable activity for the poor, even when the stones are found in low concentrations. Artisanal mining thus contributes to regionally based operations that contrast sharply with the industrial-level enclaves of other extraction sectors. From the diamond belt of West Africa to that of Central Africa (Central African Republic and Kassai-Northeast Angola), from the emeralds and amethysts of Colombia and Minas Gerais in Brazil to the sapphires and rubies of southern Sri Lanka, from the Thai-Cambodian border to the region of Mogok in Burma, the geography of artisanal mining overlaps that of poor areas, often enclaves or isolated regions, some of them in conflict or newly post-conflict. The factors that influence the dynamics of regions with deposits of precious stones do not simply relate to matching demand with a supply that depends on geological luck. The known concentrations have to be too low to warrant mechanization, and the level of poverty or of crisis has to be kept elevated enough to make it worthwhile for the locals to continue operations that are arduous, dangerous, and not reliably profitable. Strong Asian demand for sapphires and rubies will not be adequate to prevent the decline in output in Thailand, the victim of that country's relative increase in wealth. East Africa (Tanzania, Kenya, Madagascar, Somalia), which has many small scattered deposits in countries with poor political and economic conditions, might be the next region to be asked to meet future demand, and if so those will see the greatest number of new "gem rushes."

Despite its wealth of subject-matter, this dossier omits many important topics. Some geographical regions are missing, including the Middle East, Russia, the Nordic countries, and the major emerging countries apart from China. Geographic differences in the new energy nationalisms are barely touched on, nor are analyses of environmental hazards or the landscapes of resource extraction. Petro-politics and the "resource wars" are other broad topics only mentioned in passing. This issue of Echogéo simply lays some of the groundwork for a subject that will become more important in years to come as expected changes in the energy field begin to come about. For while no one is yet in a position to predict the exact timing and character of these changes, 
we can nonetheless conjecture that this reshuffling of the cards in the energy field and hence in the corridors of power will have massive implications.

\section{BIBLIOGRAPHIE}

Alden C., Large D., Soares de Oliveira R. (eds.), 2008. China Returns to Africa. A Rising Power and a Continent Embrace. $382 \mathrm{p}$.

Antheaume B., Giraut F. (eds.), 2005. Le territoire est mort, vive les territoires! Une (re)fabrication au nom du développement. Paris, IRD Editions, $384 \mathrm{pp}$.

Arrault J.B., 2005. Du toponyme au concept? Usages et significations du terme archipel en géographie et dans les sciences sociales. L'Espace géographique, 2005-4, pp. 315-328.

Bauman Z., 2000. Liquid modernity. Cambridge, Polity Press, 240 pp.

Bayart J.F., 1989. L'État en Afrique. La politique du ventre. Paris, Librairie Erthème Fayard, 2nd edition, 2006, $439 \mathrm{pp}$.

Brunet R., 2004. Le diamant. Un monde en révolution. Paris, Belin, 416 pp.

Campbell B. (ed.), 2009. Mining in Africa. Regulation and Development. London, New York, Pluto Press, International Development Research Center, The Nordic Africa Institute, 276 pp.

Donner N., 2003. "Chad Development Project" : Approche d'un projet pétrolier à l'heure du développement durable. Le projet Exxon Mobil au Tchad. Master's thesis in Geography, Joseph Fourier University, Grenoble I, 166 pp.

Donner N., 2009. The Myth of the Oil Curse: Exploitation and Diversion in Equatorial Guinea. AfroHispanic Review, vol. 28, No. 2, pp. 21-42.

Ferguson J., 1999. Expectations of Modernity. Myths and Meanings of Urban Life on the Zambian Copperbelt. Berkeley, Los Angeles, London, University of California Press, 326 pp.

Ferguson J., 2006. Global Shadows. Africa in the Neoliberal World Order. Durham and London, Duke University Press, 257 pp.

Gabriel-Oyhamburu K., 2010. Le retour d'une géopolitique des ressources ? L'Espace Politique [online], 12 | 2010-3, posted February 11 2011, consulted September 8 2011. URL: http:// espacepolitique.revues.org/index1796.html Gottmann J., 1952. La politique des États et leur géographie. CTHS, 261 pp.

Hönke J., 2010. New political topographies. Mining companies and indirect discharge in Southern Katanga (DRC). Politique africaine, No. 120, December 2010, pp. 105-128.

Magrin G., 2003. Les enjeux d'un enrichissement pétrolier en Afrique centrale. Le cas du Tchad. Paris, Grafigéo No. 22, in the series Mémoires et documents de l'UMR PRODIG, 93 pp.

Magrin G, van Vliet G., 2005. Greffe pétrolière et dynamiques territoriales : l'exemple de l'on shore tchadien. Afrique contemporaine, No. 216, pp. 87-105. 
Magrin G., van Vliet G., van Dessel B., Chabason L., 2011. La Mauritanie et la mer : et si le pétrole aidait à mieux gérer l'insécurité écologique ? Natures, Sciences et Sociétés, 3/2011 (in press).

Magrin, 2011. Des rentes aux territoires. Contribution pour une géographie du développement en Afrique. Habilitation à diriger des recherches, University of Paris 1 Panthéon Sorbonne, Volume 3, essay, 447 pp.

Martinez L., 2010. Violence de la rente pétrolière : Algérie - Irak - Libye. Paris, Presses de la fondation nationale des sciences politiques, $229 \mathrm{pp}$.

Mbodj F.B., 2011. Boom aurifère à l'est du Sénégal, à l'ouest du Mali et au nord-est de la Guinée : mutations socio-économiques et spatiales d'anciennes marges économiques et géographiques. Doctoral thesis in Geography, University of Paris 1 - Panthéon Sorbonne, May 2011.

Megret Q., 2011. De l'inscription en bourse à l'exploration en brousse. La double vie d'une multinationale minière junior. Carnets de géographes [online], No. 2, March 2011, section Carnets de terrain, consulted September 52011 http://www.carnetsdegeographes.org/carnets_terrain/ terrain_02_04_Megret.php

Perrier-Bruslé L., 2008. Le gaz bolivien. La Bolivie face à son avenir. Outre-Terre, Revue française de géopolitique, Eres, No. 18, 2007/1, pp. 235-251 http://www.cairn.info/revue-outre-terre-2007-1p-235.htm

Pourtier R., 1989. Le Gabon, vol. 2, État et développement. Paris, L'Harmattan, 344 pp.

Raffestin C., 1980. Pour une géographie du pouvoir. Paris, Librairies techniques, 249 pp.

Rosser A., 2006. The Political Economy of the Resource Curse: A Literature Survey. IDS Working paper No. 268, Centre for the Future State, $34 \mathrm{pp}$.

Sloterdijk P., 2005. Écumes (Sphères III). Paris, Hachette littératures.

Soares de Oliveira R., 2007. Oil and Politics in the Gulf of Guinea. London, Hurst \& Company, 379 pp. Soares de Oliveira R., 2008. Making Sense of Chinese Oil Investment in Africa, Alden C., Large D., Soares de Oliveira R. (eds.), China Returns to Africa. A Rising Power and a Continent Embrace, London, Hurst \& Company, pp. 83-109.

van Vliet G., Magrin G. (eds.), 2012. La Chine sur la piste du pétrole africain : la CNPC et les enjeux environnementaux au Tchad. AFD, collection Focales, Quae (forthcoming 2012).

van Vliet, G., 1998. Activités minières, barrages, et problématiques de négociation : hypothèses pour une réflexion. Powerpoint presentation.

van Vliet G., Magrin G., 2009. Public steering in the hydrofuel sector. Conditions for trajectory bifurcation in Chad and Mauritania. $21^{\text {st }}$ World Congress of Political Science, Santiago de Chile, July 12-16 2009.

\section{NOTES}

1. EchoGéo No. 8, March-May2009 http://echogeo.revues.org/10263

2. A research group was created in 2009 by historians from the CNAM and EHESS (France) to study "industrial excesses" in the city and the conflicts they generate. The concept of "industrial excesses" ("débordements"), which is still to be defined precisely, includes accidents, pollution, hazards, and risks associated with industrial activities. Extractive industries play a major role here. http://www.debordementindustriel.fr/modeles/presentation.htm 
3. See the editorial by Alain Juppé, "l'Afrique doit être notre "nouvelle frontière" ("Africa should be our "new frontier") in the dossier "Afrique, nouvelle terre de conquête" ("Africa, a new territory to conquer"), Diplomatie No. 52, September 2011 (p. 10).

4. This term refers to the idea that in "fragile" states oil revenues allow tiny elites, freed of all social or political responsibility toward their fellow-citizens, to remain in power indefinitely, since these revenues finance the means of repression and guarantee unconditional support internationally for the regimes.

5. By contrast, in Latin America starting in the mid-2000s, the nationalization of hydrocarbons in Bolivia and the renegotiation of contracts in Ecuador and Venezuela are more typical of a postneoliberal period.

6. In the petroleum industry, deep-sea exploration remains the preserve of the Western majors. While the Brazilian company Petrobras has recently made notable advances in this domain, Chinese and Indian companies still play an insignificant role.

INDEX

Thèmes : Sur le Champ - Sur le Terrain 